MACMULAN MODERN DRAMATISTS 
Macmillan Modern Dramatists

Series Editors: Bruce King and Adele King

\section{Published titles}

Reed Anderson, Federico Garcia Lorca

Eugene Benson, J. M. Synge

Renate Benson, German Expressionist Drama

Normand Berlin, Eugene O'Neill

Michael Billington, Alan Ayckbourn

John Bull, New British Political Dramatists

Denis Calandra, New German Dramatists

Neil Carson, Arthur Miller

Maurice Charney, Joe Orton

Ruby Cohn, New American Dramatists, 1960-1980

Bernard F Dukore, American Dramatists, 1918-1945

Bernard F Dukore, Harold Pinter

Arthur Ganz, George Bernard Shaw

James Gibbs, Wole Soyinka

Frances Gray, John Arden

Julian Hilton, Georg Büchner

David L Hirst, Edward Bond

Helene Keyssar, Feminist Theatre

Bettina L Knapp, French Theatre 1918-1939

Charles Lyons, Samuel Beckett

Jan McDonald, The 'New Drama', 1900-1914

Susan Bassnett-McGuire, Luigi Pirandello

Margery Morgan, August Strindberg

Leonard C. Pronko, Eugène Labiche and Georges Feydeau

Jeanette L Savona, Jean Genet

Claude Schumacher, Alfred Jarry and Guillaume Apollinaire

Laurence Senelick, Anton Chekhov

Theodore Shank, American Alternative Theatre

James Simmons, Sean O'Casey

David Thomas, Henrik Ibsen

Dennis Walder, Athol Fugard

Thomas Whitaker, Tom Stoppard

Nick Worral, Nikolai Gogol and Ivan Turgenev

Katharine Worth, Oscar Wilde

Further titles in preparation 


\section{MACMULIAN MODERN DRAMATISTS}

\section{THIS}

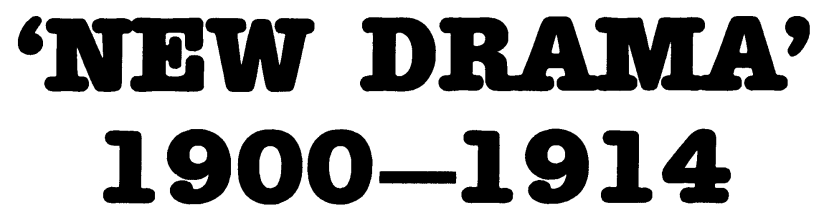

Harley Granville Barker, John Galsworthy, St John Hankin, John Masefield

\section{Jan McDonald}

Professor of Drama, University of Glasgow

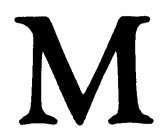


(C) Jan McDonald 1986

Softcover reprint of the hardcover 1st edition 1986 978-0-333-30873-8

All rights reserved. No reproduction, copy or transmission of this publication may be made without written permission.

No paragraph of this publication may be reproduced, copied or transmitted save with written permission or in accordance with the provisions of the Copyright Act 1956 (as amended).

Any person who does any unauthorised act in relation to this publication may be liable to criminal prosecution and civil claims for damages.

First published 1986

Published by Higher and Further Education Division MACMILLAN PUBLISHERS LTD

Houndmills, Basingstoke, Hampshire RG21 2XS

and London

Companies and representatives

throughout the world

Typeset by Type Generation Ltd, London EC1

McDonald, Jan

The 'New Drama' 1900-1914. - (Macmillan modern dramatists)

1. Galsworthy, John, 1867-1933 - Criticism and interpretation.

2. Granville-Barker, Harley - Criticism and interpretation.

3. Hankin, St John - Criticism and interpretation.

I. Title

822'.912'09 PR6013.A5Z/

ISBN 978-0-333-30874-5 ISBN 978-1-349-18132-2 (eBook)

DOI 10.1007/978-1-349-18132-2 


\section{Contents}

List of Plates

Acknowledgments

Editors' Preface

Introduction

vi

vii

viii

1

PART 1 THE THEATRES

The Court Theatre (1904-1907) 11

The Savoy Theatre (1907-1908) 34

Frohman's Repertory Season (1910) 37

The Provincial Repertory Movement (1908-1914) 44

\section{PART 2 PLAYWRIGHTS AND PLAYS}

1 Harley Granville Barker: The Marrying of Ann

Leete; The Voysey Inheritance; Waste;

The Madras House

2 John Galsworthy: The Silver Box; Joy; Strife;

Justice

3 St John Hankin: The Return of the Prodigal;

The Charity that began at Home; The Cassilis

Engagement; The Last of the De Mullins

4 John Masefield: The Campden Wonder;

The Tragedy of Nan

Notes

Bibliography

Index 


\section{List of Plates}

1 Harley Granville Barker

2 John Galsworthy

3 John Masefield

$(1,2,3$, Courtesy BBC Hulton Picture Library.

4 The Marrying of Ann Leete, Royal Shakespeare

Company 1975. Oliver Cotton as Abud, Mia Farrow as Ann Leete

(C) John Haynes.

5 The Marrying of Ann Leete, 1975. Mia Farrow as Ann Leete

(C) John Haynes

6 The Voysey Inheritance, Kingsway Theatre, 1912.

(Courtesy Mander and Mitchenson Theatre Collection)

7 Waste, Royal Shakespeare Company, 1985. Judi

Dench as Amy and Maria Aitken as Frances Trebell

(C) Donald Cooper

8 Waste, 1985. Judi Dench as Amy, David Massey as Trebell

(C) Donald Cooper

9 The Madras House, National Theatre, 1976. Ronald Pickup as Philip, Helen Ryan as Jessica

(C) John Haynes

10 The Madras House, 1976. Paul Schofield as

Constantine and Mannequin

(C) John Haynes

11 Strife, The National Theatre, 1978. Michael Bryant as Roberts, Andrew Cruikshank as Anthony

(C) Donald Cooper

12 Strife, 1978. Brian Kent as Frost, Andrew

Cruikshank as Anthony

(C) Donald Cooper 


\section{Acknowledgements}

I should like to thank the staff of the Enthoven Collection of the Victoria and Albert Museum, of the British Library and of the British Theatre Association; William Gaskill, director of The Madras House for the National Theatre, and Deidre Clancy, the designer, for granting me interviews; the staff of the Royal Shakespeare Company for making available material relating to the production of The Marrying of Ann Leete and of the National Theatre for similar material relating to Strife; the BBC for allowing me to view several times the recordings of The Voysey Inheritance and Waste. I am grateful to the Court of the University of Glasgow for allowing me a term's study leave to complete the book, and to Fiona Selkirk of the Publications Office for providing me with a hide-out in which to do so. Thanks are also due to my colleagues who read and offered advice on the manuscript in various stages of its completion, the late Professor J.F. Arnott, Greg Giesekam, Dr R.J. Lyall and Claude Schumacher, and to Joyce Allen and Valerie Eden who typed it. Above all, I should like to convey my gratitude to Sarah Mahaffy for her encouragement, her constructive criticism and her neverending patience.

To

Ian, Katie and Anne-Marie, in spite of whom . . . 


\section{Editors' Preface}

The Macmillan Modern Dramatists is an international series of introductions to major and significant nineteenth and twentieth century dramatists, movements and new forms of drama in Europe, Great Britain, America and new nations such as Nigeria and Trinidad. Besides new studies of great and influential dramatists of the past, the series includes volumes on contemporary authors, recent trends in the theatre and on many dramatists, such as writers of farce, who have created theatre 'classics' while being neglected by literary criticism. The volumes in the series devoted to individual dramatists include a biography, a survey of the plays, and detailed analysis of the most significant plays, along with discussion, where relevant, of the political, social, historical and theatrical context. The authors of the volumes, who are involved with theatre as playwrights, directors, actors, teachers, and critics, are concerned with the plays as theatre and discuss such matters as performance, character interpretation and staging, along with themes and contexts.

BRUCE KING

ADELE KING 